A publication of the Muma College of Business | University of South Florida

Volume 6

Number 17

17 JULY 2021

ZAHIDAH BTE RAIMY, TEO YI LING, VALENTINO TAN, JOHNATHAN TAN, CHRISTINA

LAM, NG YIN KAI

\title{
SUSTAINING A HOTEL BUSINESS DURING CRISIS: A SINGAPORE LUXURY HOTEL'S JOURNEY DURING COVID- $19^{1}$
}

\author{
What should Richard decide for the future of Hotel J?
}

Richard Ang, a Singaporean general manager at Hotel J, aimed to be a strong leader during the COVID19 disruption. Richard sat in his office deep in thought as earlier in the day, he had attended a board meeting with his management team to discuss strategies. He wanted to ensure the safety of in-house guests and employees whilst effectively managing costs to sustain the hotel business during the crisis. Richard knew that this was not an easy decision to make, and how could he choose among the three options based on the uncertainty of the pandemic.

Tourism business was continually growing and doing well, according to Singapore Tourism Statistics 2019, Singapore recorded a total of 18.5 million international visitors who came to Singapore in 2019, and a total of S\$27.1 billion was spent in 2018 (Singapore Tourism Board, 2019). However, the spread of COVID-19 in the early 2020 had caused many countries to implement nationwide lockdowns and restricted international travel to curb the proliferation of the virus. In Singapore, the government imposed stringent measures such as increasing health, hygiene and sanitation measures, halting social activities, compulsory donning of masks in public, and compulsory quarantine for anyone traveling to Singapore.

The Singapore government employed the help of hotels to act as quarantine facilities to house individuals returning from overseas who were required to take fourteen days Stay-Home Notice (SHN). Many hotels expressed interest in accommodating SHN guests, as this option offered hotels a source of revenue, and the government remunerated the hotels accordingly despite the uncertain times. As COVID-19 infection rates in Singapore declined, the government began reducing stringent lockdown measures and to allow for small social gatherings. Additionally, hotels that were used as quarantine facilities could restart its food and beverage $(\mathrm{F} \& \mathrm{~B})$ operations albeit restricted to serve in-house dining. This created a spur in the market where many hotels began returning to regular operations so that losses could be recuperated. Concurrently, the government offered Hotel J an extension of the SHN hotel contract. Upon hearing the news, Richard gathered the team leaders to discuss on the possible strategies for Hotel J. After failing to agree on a strategy and ending in a stalemate, no conclusion was agreed upon and the meeting was adjourned until the following day.

${ }^{1}$ Copyright (C) 2021, Zahidah Bte Raimy, Teo Yi Ling, Valentino Tan, Johnathan Tan, Christina Lam, Ng Yin Kai. This case was prepared for the purpose of class discussion, and not to illustrate the effective or ineffective handling of an administrative situation. Names and some information have been disguised. This case is published under a Creative Commons BY-NC license. Permission is granted to copy and distribute this case for non-commercial purposes, in both printed and electronic formats. 
RAIMY, LING, TAN, TAN, LAM, KAI

\section{Hotel J}

Hotel $\mathrm{J}$ is a luxury hotel opened in 2015 and has since grown to become one of Singapore's leading luxury hotels. The hotel has 320 rooms and is located in the central business district area. It is conveniently accessible to shopping malls, tourist attractions and surrounded with many dining options. The hotel is also equipped with facilities such as spa, meeting rooms, swimming pool, gym, club lounge and restaurants. Prior to COVID-19, Hotel J enjoyed a healthy occupancy of $85 \%$ with a decent average daily rate (ADR) of S\$460. Its main clientele includes international business travelers from the United States, United Kingdom, and Australia, whose ages range from 30s to 50s. Hotel $\mathrm{J}$ had an intention to attract the China and India markets, but this strategy was foregone due to the travel restrictions caused by COVID19.

With the non-existent tourism demand, Hotel J took up the offer from the Singapore Government in April 2020 to be a dedicated quarantine facility for SHN guests returning from overseas. After signing a contract with the Singapore Tourism Board, Hotel J was employed as a dedicated quarantine / SHN facility and overhauled its amenities to cater to the safety measures set out by the government. Hotel J also had to ensure that the staff were able to carry out the deep sanitation procedures and were competent in handling emergency or contingency situations. The luxurious rooms in Hotel J would provide comfort for quarantine guests via advanced technology as their 14-day isolation in the room might cause stress or anxiety. The SHN contract originally was catered to returning Singaporeans and Permanent Residents during the second quarter of 2020. However, it was then extended until the end of 2020 to cater to travelers that entered Singapore through the air travel bubble. This helped Hotel J to alleviate the financial pressure during the COVID-19 period and safeguard hundreds of employee jobs. Moreover, Richard felt that it was a national duty to support the government and help Singapore in times of difficulty, especially, with the increasing number of COVID-19 cases in Singapore in April.

\section{COVID-19 and its Effects on Singapore}

COVID-19 was first discovered in Wuhan, China, on 31 December 2019 (WHO, 2020a) and the name was derived from CO for corona, VI for virus, D for disease and "19" for the year (Channel News Asia, 2020a). COVID-19 is a respiratory-related novel coronavirus disease with symptoms such as fever, cough and fatigue and some might experience headache, sore throat, accompanied by the loss of taste or smell. It spreads through respiratory droplets from an infected individual's sneezes or saliva and objects or surfaces contaminated by these droplets could also be transmitted to individuals when they touch these objects or surfaces. (WHO, 2020a). The World Health Organization declared COVID-19 a pandemic on 11 March 2020 (WHO, 2020b) as it spread worldwide due to the international air travel of tourists and workers from affected regions.

Singapore was among the top three countries in Asia with the highest COVID-19 cases during the early stages of the virus outbreak with the first case being detected on 23 January 2020 whom stayed at one of the resorts in Sentosa (Ministry of Health, 2020a; Toh, 2020; Yong, 2020). Subsequently, more hotels were identified as being visited by infected COVID-19 patients. There was also a cluster outbreak at a hotel in Orchard due to an international business conference event whereby some event delegates were discovered to have spread the virus back home upon return (Tay, 2020b; The Straits Times, 2020a).

The risk assessment of Singapore was raised from Disease Outbreak Response System Condition (DORSCON) Yellow to Orange (Exhibit 1) on 7 February 2020 due to an increase in local cases that were unlinked to any known COVID-19 cases or travel history to China (Ministry of Health, 2020b). The number of COVID-19 cases surged continuously as Singaporeans returned from overseas, and many new 
clusters emerged from the foreign worker dormitories (Badalge, 2020; Yong, 2020). The tourist arrivals plunged to its lowest in Singapore's history in April 2020 (Singapore Tourism Analytics Network, 2020; Tay, 2020c). Thus, in order to curb the spread from arrivals into the community, hotels in Singapore were used as isolation or SHN facilities for patients to recover from the virus to prevent overcrowding in hospitals and returning residents from countries with severe COVID-19 surges (Chew, 2020a; Tay, 2020d).

Singapore went into a partial lockdown with "Circuit Breaker" from 7 April 2020 to 4 May 2020 and was later extended to 1 June 2020 (Badalge, 2020; Baker, 2020a; Ministry of Health, 2020c). The recovery of Singapore after "Circuit Breaker" was captured in three phases (Exhibit 2) to ensure the safe reopening of the economy. During this lockdown, non-essential workplaces had to be closed, hotel operations were halted, F\&B operators could only provide delivery and takeaway services, residents were highly encouraged to stay home and wearing masks were compulsory when outside of home (Badalge, 2020; Gov.sg, 2020b; The Straits Times, 2020b).

On 3 July 2020, the Singapore Tourism Board announced an advisory for hotels to reopen with Safety Management Measures in place (Singapore Tourism Board, 2020a). This included imitating hotel occupancy and a stricter cleaning and disinfection regime (Awang, 2020; Channel News Asia, 2020b; Chew, 2020b; Low \& Ng, 2020; Tang, 2020). Furthermore, audit initiatives were implemented by the government, providing hotels with a "SG Clean" certification upon meeting the seven criteria from the National Environment Agency (Singapore Tourism Board, 2020b) (Exhibit 3). This initiative aimed to provide locals and visitors with the confidence to visit hotels.

Singapore was the top Asia Pacific travel destination for international visitors, however, the restriction in travel had resulted in a continuous decline in Singapore's hotel occupancy rates (STR, 2020). The loss of inbound businesses had resulted in hotels targeting the local market to survive. Singapore's Prime Minister encouraged citizens to patronize hotels for local staycation to support the hotel industry during the pandemic, a low time for the hotel industry (Chua, 2020). The Singapore Tourism Board introduced a S\$45 million campaign, "SingapoRediscovers", to provide support for the local tourism operators which included bundles for a staycation (Chew, 2020c; Lim, 2020). As part of the campaign, each Singaporean was given $\mathrm{S} \$ 100$ vouchers to spend on local tourism products such as visiting tourist attractions and hotels. In order to ensure hygiene and cleanliness could meet customers' expectations, hotels began providing hygiene kits consisting of masks, hand sanitizers and disinfecting wipes.

Technological advancements had revolutionized the sanitation practices for hotels through the use of electrostatic sprays, ultraviolet light and robot cleaners (Lim \& Tan, 2020). Hotels were encouraged to adopt digitalization, install transparent barriers at the check-in counters and issue softcopy receipts (Singapore Hotel Association, 2020). Hotels also introduced private in-room activities such as cooking and fitness sessions through video-conferencing platforms to reduce interactions with other guests and staff (Chew, 2020a). These measures taken by hotels were evident that COVID-19 had prompted changes in the industry.

As of 14 December 2020, there had been over 58,000 cases and 29 deaths in Singapore alone (Upcode Academy, 2020) and the country was at the second phase since 18 June 2020 where the majority of workplaces and activities had resumed with a restriction of five individuals for social gatherings. The best prevention was to maintain physical distance, wear masks, use of alcohol-based hand sanitizers, practice respiratory hygiene and healthy living (WHO, 2020d). The long-waited Phase 3 of Singapore's reopening 
started on December 28; it allowed social gatherings of up to eight people in public. Singapore was the first country in South East Asia to receive the first shipment of the approved Pfizer-BioNTech COVID-19 vaccine in late December (CNA, 2020).

The complete timeline for COVID-19 in Singapore is summarized in Exhibit 4.

\section{Hotel Industry in Singapore}

As shown in Table 1, the supply of hotel rooms in Singapore grew at an approximate rate of $20 \%$, from 52,576 rooms in 2015 to 63,122 rooms in 2019 . The growth in hotel supply was attributable to the strong demand from international visitor arrivals, which had increased over the past five years to a record of 19.1 million in 2019, an increase of $3.3 \%$ compared to previous years.

Table 1: Singapore Supply of Hotels Rooms - Year (Source: Singapore Tourism Analytics Network, 2020)

\begin{tabular}{|l|l|l|l|l|l|}
\hline & 2015 & 2016 & 2017 & 2018 & 2019 \\
\hline $\begin{array}{l}\text { Gazetted } \\
\text { No. of Rooms }\end{array}$ & 52,576 & 56,816 & 58,831 & 60,601 & 63,122 \\
\hline $\begin{array}{l}\text { Gazetted } \\
\text { No. of Hotels }\end{array}$ & 223 & 237 & 243 & 250 & 260 \\
\hline
\end{tabular}

\section{COVID-19 Impact on the Hotel Industry in Singapore}

As shown in Table 2, with the outbreak of the COVID-19 pandemic, the Singapore hotel industry witnessed a 87\% year-on-year decrease in room revenue from S\$1,136.3 million in Q3 2019 to S\$150.6 million in Q3 2020. The decrease in revenue was due to the nationwide lockdown to curb the virus's spread, which led to a $99.5 \%$ decrease in international visitor arrivals from 5.0 million in Q3 2019 to 30,000 in Q3 2020.

Table 2: Singapore Tourism Industry Performance - Quarters (Source: Department of Statistics Singapore, 2020)

\begin{tabular}{|l|l|l|l|l|l|l|l|}
\hline & $\begin{array}{l}\text { Q1 } \\
\mathbf{2 0 1 9}\end{array}$ & $\begin{array}{l}\text { Q2 } \\
\mathbf{2 0 1 9}\end{array}$ & $\begin{array}{l}\mathbf{Q 3} \\
\mathbf{2 0 1 9}\end{array}$ & $\begin{array}{l}\text { Q4 } \\
\mathbf{2 0 1 9}\end{array}$ & $\begin{array}{l}\text { Q1 } \\
\mathbf{2 0 2 0}\end{array}$ & $\begin{array}{l}\text { Q2 } \\
\mathbf{2 0 2 0}\end{array}$ & $\begin{array}{l}\text { Q3 } \\
\mathbf{2 0 2 0}\end{array}$ \\
\hline $\begin{array}{l}\text { Hotel Room } \\
\text { Revenue } \\
\text { (S\$ Million) }\end{array}$ & 995.1 & 951.6 & $1,1363.3$ & $1,111.5$ & 678.4 & 130.2 & 150.6 \\
\hline $\begin{array}{l}\text { International } \\
\text { Visitor Arrivals } \\
\text { (Million) }\end{array}$ & 4.69 & 4.64 & 5.00 & 4.79 & 2.66 & 0.004 & 0.03 \\
\hline
\end{tabular}

In the same period, more than half of the 67,000 hotel rooms in Singapore were used as isolation and quarantine facilities as a way to curb the spread of the disease. These accommodations were reserved for returning residents serving their 14 days SHN (Tay, 2020f). 


\section{Luxury Hotel Industry in Singapore}

The Average Occupancy Rate of Luxury hotels was 91.1\% in Q3 2019 and decreased to 46.7\% in Q3 2020. The Average Room Rate of Luxury hotels was S\$471 in Q3 2019 and decreased to S\$291.7 in Q3 2020. As a result, the Revenue Per Available Room was S\$429 in Q3 2019 and decreased to S\$136.3 in Q3 2020 (see Table 3).

Table 3: Gazetted Hotel Statistics by Luxury Tier - Quarter (Source: Singapore Tourism Analytics Network, 2020)

\begin{tabular}{|l|l|l|l|l|l|l|l|}
\hline & $\begin{array}{l}\text { Q1 } \\
\mathbf{2 0 1 9}\end{array}$ & $\begin{array}{l}\text { Q2 } \\
\mathbf{2 0 1 9}\end{array}$ & $\begin{array}{l}\text { Q3 } \\
\mathbf{2 0 1 9}\end{array}$ & $\begin{array}{l}\text { Q4 } \\
\mathbf{2 0 1 9}\end{array}$ & $\begin{array}{l}\text { Q1 } \\
\mathbf{2 0 2 0}\end{array}$ & $\begin{array}{l}\text { Q2 } \\
\mathbf{2 0 2 0}\end{array}$ & $\begin{array}{l}\text { Q3 } \\
\mathbf{2 0 2 0}\end{array}$ \\
\hline $\begin{array}{l}\text { Average } \\
\text { Occupancy } \\
\text { Rate (\%) }\end{array}$ & 88.4 & 86.1 & 91.1 & 88.2 & 60.1 & 17.5 & 46.7 \\
\hline $\begin{array}{l}\text { Average Room } \\
\text { Rate (S\$) }\end{array}$ & 452.9 & 433.8 & 471.0 & 466.5 & 454.4 & 169.1 & 291.7 \\
\hline $\begin{array}{l}\text { Revenue Per } \\
\text { Available } \\
\text { Room }\end{array}$ & 400.4 & 374.4 & 429.0 & 411.7 & 273.2 & 29.6 & 136.3 \\
\hline
\end{tabular}

\section{Singapore Hotel Reopening Requirements}

When hotels resumed their business operations, they needed to adhere to the safe management measures set. According to Singapore Tourism Board (2020c), the safe management measures set were as follows:

Hotels were required to screen every individual before they enter the hotel premises by checking their temperature and ensuring the wearing of masks. Hotels must also implement the national digital check-in system, SafeEntry, for guests to scan to check-in and check-out when entering and leaving the premises. For the hotel lobby area, seating arrangements need to be reorganized to ensure one-meter safe distancing among individuals. Queue markers were also needed at the reception, lift lobby, and smoking area. Furthermore, hotels must display notices to remind guests of the safety prevention and control measures. For instance, signages were to be placed at the lift lobby to remind guests of the maximum number of people allowed in the lift.

Hotels were required to implement staggered check-in and check-out timings to avoid overcrowding at the lobby during peak hours. Shared facilities such as gyms and swimming pools also practiced staggered timings to reduce crowding. In addition, hotels had to deploy safety ambassadors to prevent and disperse crowds in public areas within the hotel. 
For cleanliness and sanitation measures, hotels were required to use hospital-grade disinfectants. High touch areas in the hotel such as lift buttons, handrails, door handles, and reception counters were also required to be regularly disinfected to ensure sanitation. Shared items such as keycards, needed to be sanitized before being handed to guests. It was also mandatory for hotels to provide disinfecting agents such as hand sanitizer or disinfectant wipes at accessible areas of the hotel.

Hotels had to ensure that the heating, ventilation, and air-conditioning controls had good air quality exchange and were functioning well. Singapore Tourism Board also recommended for hotels to adopt technological measures such as online check-ins and express check-outs to avoid physical contact among people, such as cashless payment options and chatbots. Even though these measures were not mandatory for hotels to resume their business operations, the Singapore Tourism Board strongly encouraged such implementations for hotels.

\section{Current Trends in the Singapore Hotel Industry}

\section{Rise of Domestic Tourism}

There was no telling how long international travel restrictions would be in place, which had prompted countries to rely on the domestic market to sustain their tourism industry (Singapore Business Review, 2020a).

In an effort to boost domestic demand, the Singapore government set aside S\$320 million worth of vouchers to encourage about 3 million Singaporeans to support local tourism businesses (Tan, 2021). All eligible Singaporeans, age 18 years old and above, would receive $S \$ 100$ voucher credit which could be used at hotels, attractions, and tours. The "SingapoRediscovers" initiative had stimulated demand for staycation due to pent-up demand for travel (Tay, 2020g). As of March 2021, more than 760,000 Singaporeans had redeemed their vouchers, generating about $\$ \$ 108$ million in tourism spending (Koh, 2021). According to Smith Travel Research, staycation packages from hotels had led to an increased occupancy rate of $70 \%$, with sources claiming staycations as one of the most viable alternatives to hotel business afloat (Oh, 2020).

Despite the government stimulus package, three-quarters of all eligible Singaporeans had yet to utilize the vouchers, indicating there might still be a lack of demand for domestic tourism (Tan, 2021). Additionally, staycations remained largely a weekend business and were unlikely to make up for the weekday occupancies' losses (Singapore Business Review, 2020a). Therefore, Hotel J should carefully consider reopening the hotel for the staycation business to be a viable option during this pandemic.

\section{Contactless Experience}

The pandemic had brought about heightened awareness of the virus's contagiousness, which could be easily transmitted through touching common surfaces such as lift buttons, door handles, and self-service kiosks (Barron, 2020). This had brought about consumers' expectations for contactless experiences such as keyless entry, mobile check-out, contactless payment, and automated service requests.

Criton, a technology provider, conducted a survey on travelers' preferences during COVID-19. The results showed $80 \%$ of respondents would download the hotel's mobile application if it could provide contactless check-in and check-out features. Additionally, $73 \%$ of respondents would also download the mobile application if it provided mobile keycards. For F\&B, about $47 \%$ of respondents would be more inclined to order room service or patronize the hotels' restaurants if it provided the respondents with the 
option of ordering through the mobile application (Fox, 2020; Criton, 2020). These findings indicated that mobile phones played an important role and were an essential tool in ensuring a contactless experience (Fox, 2020; Criton, 2020). Another survey conducted by a software company, Metova, showed that mobile check-in, mobile keycards, and online concierge were the new contactless experience that respondents valued in their hotel stay. This survey also revealed that $86 \%$ of the respondents would choose one hotel over another if it provided a contactless experience (Hotel Business, 2020; Metova, 2020). Thus, indicating the importance of contactless experience as a deciding factor when selecting a hotel.

Overall, based on the contactless experience trend, it became a need for hotel operators in Singapore to accelerate their efforts to reduce the physical touchpoints to curb the spread of the virus. Therefore, it is important for Hotel $\mathrm{J}$ to keep up with the trends in order to not lose out to competitors during this COVID-19 period.

\section{Technology Transformation}

The COVID-19 pandemic had prompted the adoption of new technological solutions with a strong focus on reducing physical touchpoints and better sanitation practices (Chow, 2020). Notable hotels in Singapore such as Andaz and Pan Pacific had adopted a mobile chatbot system that allowed in-house guests to remotely place orders in restaurants (Chow, 2020). Other new hotel technologies included mobile check-in, self-check-in kiosks, contactless payments, cleaning robots as well as digital dining menu (Chew, 2020b; Singapore Business Review 2020b; Chandran. 2020).

The purpose of these systems was to reduce physical interaction while ensuring the hotel provides services to guests. Additionally, these technology adoptions aided in reducing manpower dependency while increasing the overall productivity of the hotel. Furthermore, recent studies had indicated how guests were receptive to a hotel's technology transformation to meet their new demands (Kim et al., 2021; Shin \& Kang, 2020).

While new hotel technologies might enhance guests' experiences, they were a costly investment (Singapore Business Review 2020b). The costs vary based on its integration capabilities and functions. These would also require an additional yearly cost for the training of staff and maintenance of the technologies. Therefore, Hotel $\mathrm{J}$ should carefully consider adopting these technological transformations to meet the new consumer demands and to maintain the hotel's competitive advantage.

\section{The Decision}

During the meeting, several strategies were discussed by Richard and the team leaders. The following options were the most viable and flexible. Among all, Richard would like to select the best option for Hotel $\mathrm{J}$ to ensure its business continuity in this crucial moment. Furthermore, out of the below three options, what is the possible and feasible strategy you could think of?

Decision 1: Hotel J to continue their contract as a quarantine facility with the government. The team leaders emphasized the prudence of retaining the current contract for the hotel as it ensured a steady stream of revenue. They also indicated how COVID-19 is continuing to be a global pandemic. Hence, it might not be advisable to convert the hotel back to regular operations with much uncertainty in the hospitality industry. However, the setback would be the room rates were pre-established by the government, which might not be optimistic. Minister Lawrence Wong, the COVID-19 task force chief, 
stated that "It may take four to five years before the COVID-19 pandemic ends, and the world can look to a "post-COVID normal" (Chew, 2021).

Decision 2: Hotel $\mathrm{J}$ to discontinue its contract as a quarantine facility and to reopen as a staycation hotel by following the guidelines of the Singapore hotel reopening requirements. Some leaders indicated that with the decreasing infection rates in Singapore, it might be beneficial to reopen the hotel and follow the basic guidelines of the government measures with the assumption that the hospitality industry would soon return to normalcy. Furthermore, with the possible newfound development of the COVID-19 vaccine, the recovery of the hotel industry might begin from the second quarter of 2021. In addition, if the travel bubble works well as planned, they could start taking inbound guests from the designated countries/cities, such as Hong Kong.

Decision 3: Hotel J to discontinue its contract as a quarantine facility and revamp the hotel by implementing new technological trends to reduce direct face-to-face contacts and innovative staying journey. Developing products in anticipation of the evolution of customers' needs before reopening as a staycation hotel. Technology had been a gateway for the hospitality industry to develop itself to adapt to the changing times (Guttentag, 2010; Kleinrichert et al., 2012). In addition, the Singapore government has been rolling out initiatives to assist in the digital transformation of hotels (IMDA, 2019). However, with the restraint on revenue for the hotel, Richard has to convince the owner to invest in the implementation of technology as a long-term strategy, at the same time to get funding from the Singapore Government.

Over the last decades, the world had encountered numerous crises. Some health experts forecasted that COVID-19 would not be the last pandemic. Therefore, Richard and his management team are required to plan and react promptly when dealing with crises. For the current situation, Richard and his management team wondered which option would be in the best interest of Hotel J. As the general manager of Hotel J, the final decision on the hotel strategy lies with him. Richard must consider the pros and cons of each option thoroughly. What would you decide if you were in Richard's role? What are the key factors you would consider before making the final decision?

\section{References}

Awang, N. (2020, July 3). Covid-19: Hotels may now apply to Govt to accept staycation bookings, subject to safety rules. TODAY. Retrieved from https://www.todayonline.com/singapore/covid-19hotels-may-now-apply-government-accept-staycation-bookings-subject-safety-rules

Badalge, K. N. (2020, April 30). Here's what life looks like right now in Singapore, where an outbreak in migrant worker dormitories has led to new lockdown measures. Business Insider. Retrieved from https://www.businessinsider.com/what-life-looks-like-right-now-singapore-coronavirus-lockdown2020-4

Baker, J. A. (2020a, June 2). Singapore's circuit breaker and beyond: Timeline of the COVID-19 reality. Channel News Asia. Retrieved from https://www.channelnewsasia.com/news/singapore/covid-19circuit-breaker-chronicles-charting-evolution-12779048

Barron, P. (2020, December 7). The evolving traveler journey: 3 trends hoteliers must address today. PhocusWire. Retrieved from https://www.phocuswire.com/the-evolving-traveler-journey 
Chandran, N. (2020, September 23). Singapore hopes artificial intelligence will help boost its tourism industry. CNBC. Retrieved from https://www.cnbc.com/2020/09/24/singapore-looks-to-artificialintelligence-ai-to-boost-tourism.html

Channel News Asia. (2020a, February 12). WHO names novel coronavirus as “COVID-19." Retrieved from https://www.channelnewsasia.com/news/world/wuhan-virus-coronavirus-who-new-name12424116

Channel News Asia. (2020b, July 4). Hotels can apply to reopen for staycation bookings. Retrieved from https://www.channelnewsasia.com/news/singapore/hotels-can-apply-to-reopen-for-staycationbookings-stb-covid-19-12899606

Chew, H. M. (2020a, March 24). Returning Singapore residents from UK, US to serve stay-home notices at hotels. Channel News Asia. Retrieved from https://www.channelnewsasia.com/news/singapore/covid19-returning-singapore-residents-uk-usshn-hotels-12571490

Chew, H. M. (2020b, June 7). Contactless service and cleaning robots: Here's what your next travel experience may be like. Channel News Asia. Retrieved from https:/www.channelnewsasia.com/news/singapore/covid-19-travel-experience-hotels-contactlessservice-12792376

Chew, H. M. (2020c, July 22). S\$45 million tourism campaign launched urging locals to explore Singapore. Channel News Asia. Retrieved from https://www.channelnewsasia.com/news/singapore/singaporediscovers-45-million-tourismcampaign-stb-singapoliday-12952932

Chew, H. M. (2021, January 25). COVID-19 pandemic could last 4 to 5 years: Lawrence Wong. Channel News Asia. Retrieved from https://www.channelnewsasia.com/news/singapore/covid-19pandemic-could-last-4-to-5-years-lawrence-wong-14038700

Chow, P. (2020, September 16). (2020, June 10). Pandemic fast-tracks technology adoption among hotels. TTG Asia. Retrieved from https://www.ttgasia.com/2020/06/10/pandemic-fast-trackstechnology-adoption-among-hotels

Chua, N. (2020, March 3). PM Lee requests S'poreans go for staycations, visit local attractions to boost local industries. Retrieved from https://mothership.sg/2020/03/pm-lee-bird-park-photos/

Criton. (2020, August 18). New research reveals the technology and safety measures hotel guests want during COVID-19. https://www.criton.com/news-hub/new-research-reveals-the-technology-andsafety-measures-hotel-guests-want-during-covid-19/

Department of Statistics Singapore. (2020, December). Tourism Latest Data. Retrieved from https://www.singstat.gov.sg/find-data/search-by-theme/industry/tourism/latest-data

Gov.sg. (2020a, May 28). Ending circuit breaker: phased approach to resuming activities safely. Retrieved from https://www.gov.sg/article/ending-circuit-breaker-phased-approach-to-resumingactivities-safely 
Gov.sg. (2020b, April 11). What you can and cannot do during the circuit breaker period. Retrieved from https://www.gov.sg/article/what-you-can-and-cannot-do-during-the-circuit-breaker-period

Gov.sg. (2020c, February 6). What do the different DORSCON levels mean. Retrieved from https://www.gov.sg/article/what-do-the-different-dorscon-levels-mean

Guttentag, D. A. (2010). Virtual reality: Applications and implications for tourism. Tourism Management, 31(5), 637-651. https://doi.org/10.1016/j.tourman.2009.07.003

Hotel Business. (2020, November 17). Survey: Tech-supported, contactless stay desired by guests. https://www.hotelbusiness.com/survey-tech-supported-contactless-stay-desired-by-guests/

IMDA. (2019, November 5). Hotel industry digital plan. . Retrieved from https://www.imda.gov.sg//media/Imda/Files/Programme/SMEs-Go-Digital/Industry-Digital-Plans/Hotel-IDP/HotelIDP_Nov2019.pdf?la=en

Kim, S., Kim, J., Badu, F., Giroux, M., \& Choi, Y. (2021). Preference for robot service or human service in hotels? Impacts of the COVID-19 pandemic. International Journal of Hospitality Management, 93, 102795. https://doi.org/10.1016/j.ijhm.2020.102795

Kleinrichert, D., Ergul, M., Johnson, C., \& Uydaci, M. (2012). Boutique hotels: Technology, social media and green practices. Journal of Hospitality and Tourism Technology, 3(3), 211-225. https://doi.org/10.1108/17579881211264495

Koh, F. (2021, April 5). Over 760,000 Singaporean adults have used their SingapoRediscovers vouchers. The Straits Times. Retrieved from https://www.straitstimes.com/singapore/over-760000singaporean-adults-have-used-their-singaporediscovers-vouchers

Lim, J. (2020, July 22). STB launches S\$45m domestic tourism campaign to encourage locals to discover hidden gems in Singapore. TODAY. Retrieved from https://www.todayonline.com/singapore/stblaunches-s45m-domestic-tourism-campaign-get-locals-discover-hidden-gems-singapore

Lim, J, \& Tan, T. M. (2020, May 17). Coronavirus: Digital check-ins and lots of disinfecting as Singapore hotels gear up for new normal. The Straits Times. Retrieved from https://www.straitstimes.com/singapore/digital-check-ins-and-lots-of-disinfecting-as-hotels-gearup

Low, D., \& Ng, M. (2020, July 4). Coronavirus: Hotels can open for staycations again. The Straits Times. Retrieved from https://www.straitstimes.com/singapore/hotels-can-open-for-staycations-again

Metova. (2020, November 10). Survey reveals tech-supported, contactless 'New Normal' for hotels, resorts and casinos amid COVID-19. https://metova.com/news-survey-reveals-contactless-newnormal-for-hotels-resorts-and-casinos-amid-covid-19/

Ministry of Health. (2020a, January 23). Confirmed imported case of novel coronavirus infection in Singapore; multi-ministry taskforce ramps up precautionary measures. Retrieved from https://www.moh.gov.sg/news-highlights/details/confirmed-imported-case-of-novel-coronavirusinfection-in-singapore-multi-ministry-taskforce-ramps-up-precautionary-measures

Ministry of Health. (2020b, February 7). Risk assessment raised to DORSCON orange. Retrieved from https://www.moh.gov.sg/news-highlights/details/risk-assessment-raised-to-dorscon-orange 
Ministry of Health. (2020c). Past updates on COVID-19 local situation. Retrieved from https://www.moh.gov.sg/covid-19/past-updates

NEA. (2020). Checklist for SG Clean Programme, Singapore Licensed Hotels. Retrieved from www.moh.gov.sg

Oh, S. (2020, September 10). Singapore Helps Hoteliers With Staycation Stimulus. CoStar. https://www.costar.com/article/1566397501

Shin, H., \& Kang, J. (2020). Reducing perceived health risk to attract hotel customers in the COVID-19 pandemic era: Focused on technology innovation for social distancing and cleanliness. International Journal of Hospitality Management, 91, 102664. https://doi.org/10.1016/j.ijhm.2020.102664

Singapore Business Review. (2020a, September 3). Hospitality sector face slow recovery in H2: analyst. Retrieved from https://sbr.com.sg/hotels-tourism/in-focus/hospitality-sector-face-slow-recovery$\underline{\text { in-h2-analyst }}$

Singapore Business Review. (2020b, September 3). Hotels bank on contactless tech to entice guests during coronavirus pandemic. Retrieved from https://sbr.com.sg/hotels-tourism/in-focus/hotelsbank-contactless-tech-entice-guests-during-coronavirus-pandemic

Singapore Hotel Association. (2020). Recommended guidelines for hotels. Retrieved from https://sha.org.sg/userfiles/ckeditor/Files/Recommended\%20Guidelines\%20for\%20Hotels\%20in\% 20Phase\%20One_Factsheet_Updated\%207Jun.pdf

Singapore Tourism Analytics Network. (2020, December). Tourism Statistics. Retrieved from https://stan.stb.gov.sg/portal/tourism-statistics.html

Singapore Tourism Analytics Network. (2020, June). Monthly Visitor Arrivals. Retrieved from https://stan.stb.gov.sg/public/sense/app/254dd6c2-eaf7-46c4-bf7a-39b5df6ff847/sheet/3101ecddaf88-4d5d-be49-6c7f90277948/state/analysis

Singapore Tourism Board. (2019, February 13). Third consecutive year of growth for Singapore tourism sector in 2018. Retrieved from https://www.stb.gov.sg/content/stb/en/media-centre/mediareleases/third-consecutive-year-of-growth-for-singapore-tourism-sector-in-2018.html

Singapore Tourism Board. (2020a, July 30). Safe Management Measures for Hotels. Retrieved from https://www.stb.gov.sg/content/stb/en/home-pages/advisory-for-hotels.html

Singapore Tourism Board. (2020b, March 12). SG Clean Quality Mark Extended to Tourism and Lifestyle Businesses as part of Nationwide Efforts to Uplift Sanitation and Hygiene. Retrieved from https:/www.stb.gov.sg/content/stb/en/media-centre/media-releases/sg-cleanqualitymarkextendedtotourismandlifestylebusinessesaspar.html.html

Singapore Tourism Board. (2020c, December 1). Checklist for safe management measures for hotels. Retrieved from 
https:/www.stb.gov.sg/content/dam/stb/documents/pages/HotelsReopening/Annex\%20A_Checkli st $\% 20$ of $\% 20$ SMMs\%20for\%20Hotels_ver01Dec2020.pdf

STR. (2020, February 25). Hotel markets throughout Asia Pacific show coronavirus impact. Retrieved from https://str.com/press-release/hotel-markets-throughout-asia-pacific-show-coronavirus-impact

Tan, L. (2021, April 5). About 2.2m Singaporeans have not used their SingapoRediscovers Vouchers. The Business Times. Retrieved from https:/www.businesstimes.com.sg/government-economy/about$22 \mathrm{~m}$-singaporeans-have-not-used-their-singaporediscovers-vouchers

Tang, S. K. (2020, July 19). Singapore hotels look to woo staycationers with promotions, COVID-19 safety measures. Channel News Asia. Retrieved from https://www.channelnewsasia.com/news/singapore/hotels-reopening-staycation-deals-covid-1912940424

Tay, T. F. (2020b, February 5). Coronavirus: Grand Hyatt Singapore disinfecting rooms and public areas after 3 travellers test positive. The Straits Times. Retrieved from https://www.straitstimes.com/singapore/coronavirus-grand-hyatt-singapore-disinfecting-roomsand-public-areas-after-two-travellers

Tay, T. F. (2020c, June 5). Coronavirus: Visitor arrivals to Singapore hit historic low in April. The Straits Times. Retrieved from https://www.straitstimes.com/singapore/visitor-arrivals-to-singapore-hithistoric-low-in-april-0

Tay, T. F. (2020d, March 12). Hotels linked to coronavirus cases among tourism, lifestyle businesses awarded SG Clean mark. The Straits Times. Retrieved from https://www.straitstimes.com/singapore/hotels-linked-to-coronavirus-cases-among-tourismlifestyle-businesses-awarded-sg-clean

Tay, T. F. (2020e, September 16). All adult S'poreans to get $\$ 100$ tourism vouchers in December for staycations, attractions and local tours. The Straits Times. Retrieved from https://www.straitstimes.com/singapore/all-adult-sporeans-to-get-100-tourism-vouchers-indecember-for-staycations-attractions-and

Tay, T. F. (2020f, July 16). More than half of Singapore's hotel rooms used in Covid-19 battle, not all can reopen for staycations: STB chief. The Straits Times. Retrieved from https://www.straitstimes.com/singapore/more-than-half-of-singapores-hotel-rooms-used-in-covid19-battle-not-all-can-reopen-for

Tay, T. F. (2020g, November 24). S'poreans can redeem \$100 SingapoRediscovers Vouchers from Dec 1 via booking platforms, counters. The Straits Times. Retrieved from https://www.straitstimes.com/singapore/consumer/sporeans-can-redeem-100-singaporediscoversvouchers-from-dec-1-via-booking

The Straits Times. (2020a, February 5). Singapore business meeting linked to Malaysian, South Korean coronavirus cases. Retrieved from https://www.straitstimes.com/asia/east-asia/singapore-businessmeeting-linked-to-malaysian-south-korean-coronavirus-cases

The Straits Times. (2020b, April 7). What are the essential services that will remain open amid stricter Covid-19 measures in Singapore? Retrieved from https://www.straitstimes.com/singapore/whatare-the-essential-services-that-will-remain-open-amid-stricter-covid-19-measures-in 
Toh, T. W. (2020, January 24). Hotel rooms linked to confirmed case thoroughly cleaned, sealed off. The Straits Times. Retrieved from https://www.straitstimes.com/singapore/health/hotel-rooms-linkedto-confirmed-case-thoroughly-cleaned-sealed-off

Upcode Academy. (2020, December 7). Dashboard of the COVID-19 Virus Outbreak in Singapore. Retrieved from https://co.vid19.sg/singapore/

WHO. (2020a, April 17). Q\&A on coronaviruses (COVID-19). Retrieved from https://www.who.int/emergencies/diseases/novel-coronavirus-2019/question-and-answers-hub/q-adetail/q-a-coronaviruses

WHO. (2020b, July 30). Timeline of WHO's response to COVID-19. Retrieved from https://www.who.int/news-room/detail/29-06-2020-covidtimeline

WHO. (2020d, June 4). Coronavirus disease (COVID-19) advice for the public. Retrieved from https://www.who.int/emergencies/diseases/novel-coronavirus-2019/advice-for-public

Yong, M. (2020, April 18). Timeline: How the COVID-19 outbreak has evolved in Singapore so far. Channel News Asia. Retrieved from https://www.channelnewsasia.com/news/singapore/singaporecovid-19-outbreak-evolved-coronavirus-deaths-timeline-12639444 


\section{Biographies}

Zahidah Bte Raimy is an undergraduate from Singapore Institute of Technology,

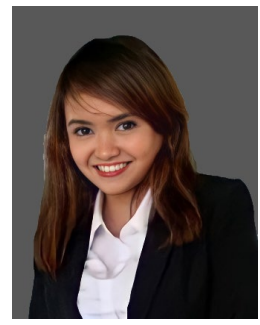
B (Hons) Hospitality Business.

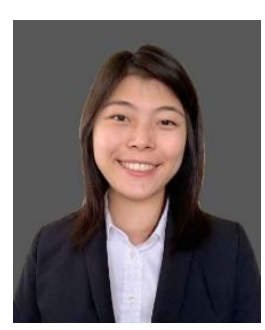

Teo Yi Ling is an undergraduate from Singapore Institute of Technology, B (Hons) Hospitality Business.

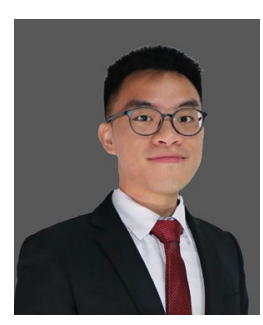

Valentino Tan is an undergraduate from Singapore Institute of Technology, B (Hons) Hospitality Business.

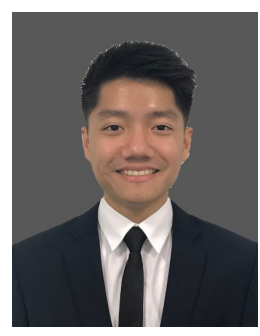

Johnathan Tan is an undergraduate from Singapore Institute of Technology, B (Hons) Hospitality Business.

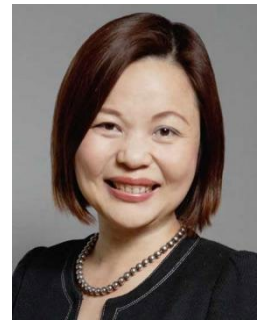

Dr. Christina Lam is an Assistant Professor and the Programme Leader of the Hospitality Business Degree programme at Singapore Institute of Technology (SIT). Prior to joining academia, she was an industry practitioner and assumed different leadership roles in the hospitality industry. Her teaching and research interests are in the area of Hospitality Consumer Behavior, Brand Management, Hotel Development and Service Quality Management. 


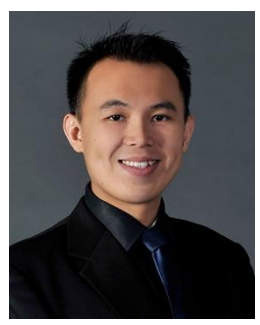

$\mathrm{Ng}$ Yin Kai is a Professional Officer at Singapore Institute of Technology, graduated from Murdoch University with a Bachelor of Commerce in Marketing, Hospitality and Tourism. He accumulated many years of industry experience in hospitality sales. 


\section{Exhibit 1: Singapore's DORSCON Alert Levels}

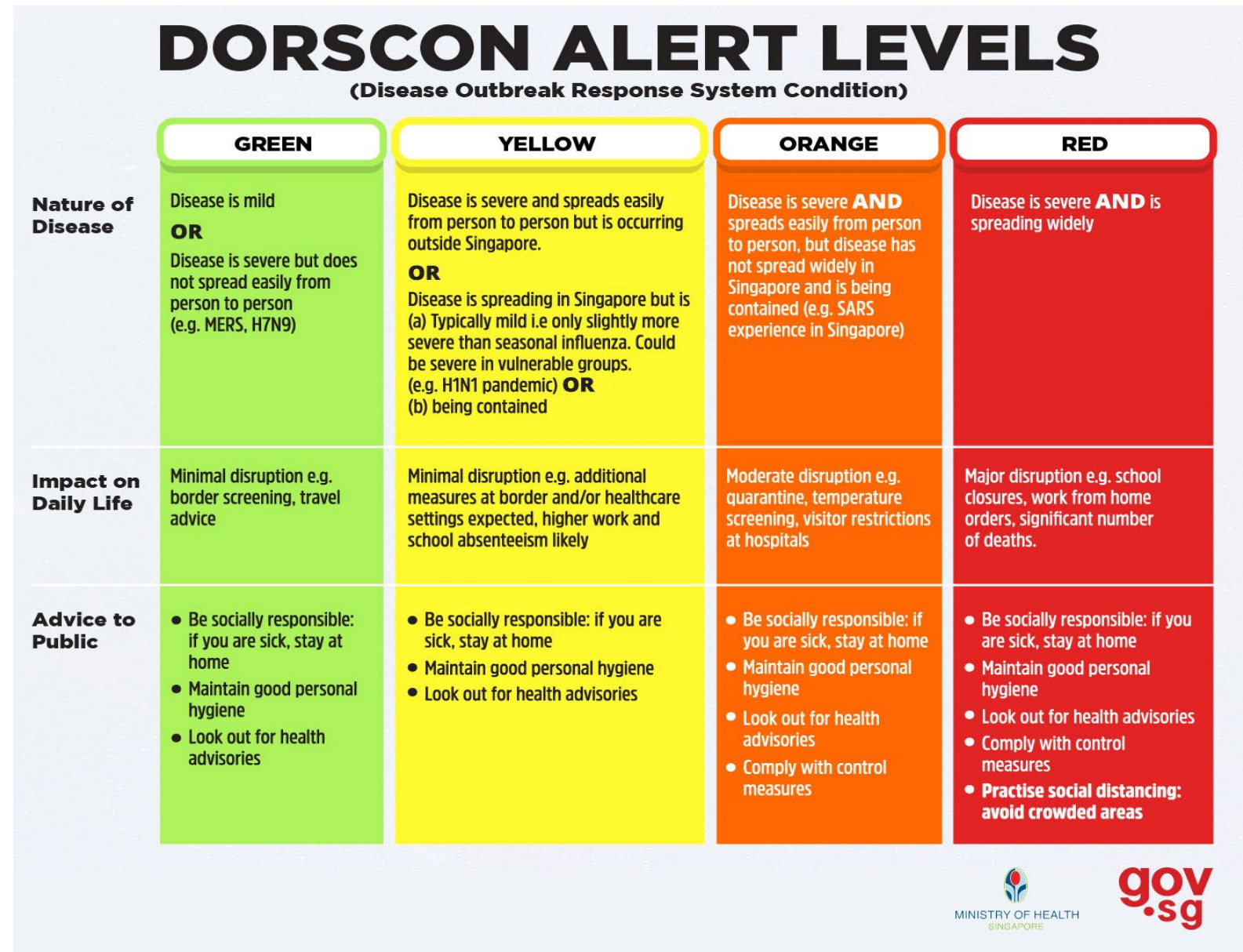

Source: (Gov.sg, 2020c) 
Exhibit 2: Singapore's Phased Approach of Reopening

\section{HOW SINGAPORE WILL SAFELY EXIT THE CIRCULT BREAKER}

Phase 1: Safe Re-opening (from 2 June)

- Businesses that do not pose high risk re-open

- Leave home only for essential activities

Phase 2: Safe Transition

- More businesses re-open with safe management measures

- All students fully return to school

- Sports \& recreation facilities re-open with safe management measures

\section{Phase 3: Safe Nation}

Gatherings and events resume with sizes limited 


\section{Exhibit 3: SG Clean Audit Criteria}

\begin{tabular}{|c|c|}
\hline 7-Points for SG Clean Programme & $\begin{array}{l}\text { Clause number for } \\
\text { Implementation } \\
\text { Requirement }\end{array}$ \\
\hline $\begin{array}{l}\text { 1. Appoint a "SG Clean" Manager to implement measures and } \\
\text { ensure compliance to checklist of SG Clean Programme. }\end{array}$ & 1 \\
\hline $\begin{array}{l}\text { 2. Have processes in place to check temperature and look out } \\
\text { for respiratory symptoms of employees, and ensure that } \\
\text { those who have visited COVID-19 affected countries with } \\
\text { travel restrictions in place or are under an active Stay-Home } \\
\text { Notice (SHN) or Quarantine Order }(\mathrm{QO}) \text { are not at the hotel. }\end{array}$ & 2 \\
\hline $\begin{array}{l}\text { 3. Where feasible and applicable, have processes in place to } \\
\text { check temperature and look out for respiratory symptoms of } \\
\text { tenants, contractors and suppliers, and ensure that } \\
\text { tenants, contractors and suppliers who have visited COVID- } \\
19 \text { affected countries with travel restrictions in place or are } \\
\text { under an active SHN or QO are not at the hotel. } \\
\text { Where feasible and applicable, have processes in place to } \\
\text { check temperature and look out for respiratory symptoms of } \\
\text { hotel guests }{ }^{1} \text { and event guests. } \\
\text { Implement appropriate safe distancing measures for guests. }\end{array}$ & 3 \\
\hline $\begin{array}{l}\text { 4. Step up frequency of disinfection for all common facilities, } \\
\text { and ensure that employees observe good personal hygiene. }\end{array}$ & 4 \\
\hline $\begin{array}{l}\text { 5. Check that procedures are in place to manage COVID-19 } \\
\text { suspect cases. }\end{array}$ & 5 \\
\hline $\begin{array}{l}\text { 6. Check there are documents and records of all preventive } \\
\text { measures. }\end{array}$ & 6 \\
\hline $\begin{array}{l}\text { 7. Ensure compliance to government orders, guidelines and } \\
\text { health advisories on the COVID-19. }\end{array}$ & 7 \\
\hline
\end{tabular}

Source: (NEA, 2020) 


\section{Exhibit 4: Singapore COVID-19 Timeline}

\begin{tabular}{|c|c|}
\hline Date & Details \\
\hline 31 December 2019 & $\begin{array}{l}\text { A severe cluster of pneumonia cases was detected in Wuhan, China, and } \\
\text { was reported to the World Health Organization }\end{array}$ \\
\hline 23 January 2020 & First confirmed case in Singapore \\
\hline 4 February 2020 & First cluster in Singapore at Yong Thai Hang Medical Hall \\
\hline 7 February 2020 & Singapore's DORSCON level changed from yellow to orange \\
\hline 11 February 2020 & World Health Organization named the novel coronavirus as "COVID-19" \\
\hline 17 February 2020 & $\begin{array}{l}\text { The Singapore government announced a compulsory } 14 \text { days Stay-Home } \\
\text { Notice to be implemented for all Singapore residents and internationals } \\
\text { returning from overseas }\end{array}$ \\
\hline 29 February 2020 & More than 100 cases of COVID-19 reported in Singapore \\
\hline 13 March 2020 & Events with over 250 participants are to be postponed or cancelled \\
\hline 15 March 2020 & More than 200 cases of COVID-19 reported in Singapore \\
\hline 20 March 2020 & $\begin{array}{l}\text { There is a slight decrease in local transmission but a rise in imported cases } \\
\text { due to Singaporeans returning from overseas }\end{array}$ \\
\hline 21 March 2020 & Singapore announced the first 2 deaths due to COVID-19 \\
\hline 24 March 2020 & $\begin{array}{l}\text { Local cases begin to rise } \\
\text { Singapore forces closure of entertainments, attractions and venues to curb } \\
\text { the spread of COVID-19 }\end{array}$ \\
\hline 27 March 2020 & More than 700 cases of COVID-19 reported in Singapore \\
\hline 31 March 2020 & Imported cases decline but local cases continue to rise \\
\hline 1 April 2020 & More than 1,000 cases of COVID-19 reported in Singapore \\
\hline 7 April 2020 & Circuit Breaker commenced \\
\hline 9 April 2020 & $\begin{array}{l}\text { Local cases continue to rise due to Singapore migrant dormitory worker } \\
\text { COVID-19 infections }\end{array}$ \\
\hline 17 April 2020 & More than 5,000 cases of COVID-19 reported in Singapore \\
\hline
\end{tabular}




\begin{tabular}{|c|c|}
\hline 21 April 2020 & $\begin{array}{l}\text { Announcement of Circuit Breaker to be extended from 4th May to 1st June } \\
2020\end{array}$ \\
\hline 2 May 2020 & $\begin{array}{l}\text { Announcement of the ease of Circuit Breaker measures where some } \\
\text { businesses such as barbers and laundry are allowed to resume operations } \\
\text { on } 12 \text { May } 2020\end{array}$ \\
\hline 1 June 2020 & Circuit breaker lifted \\
\hline 2 June 2020 & $\begin{array}{l}\text { Commencement of Phase } 1 \text { reopening } \\
\text { Few businesses gradually reopen. Activities such as the family visit of } 2 \\
\text { persons and reopening of schools. }\end{array}$ \\
\hline 8 June 2020 & Singapore established the first bilateral green lane with China \\
\hline 19 June 2020 & $\begin{array}{l}\text { Commencement of Phase } 2 \text { reopening } \\
\text { More businesses gradually reopen with some workers allowed back to } \\
\text { offices. Activities such as dining-in and increased family pax visitation to } \\
5 \text { persons allowed. }\end{array}$ \\
\hline 3 July 2020 & $\begin{array}{l}\text { Singapore Tourism Board announced that hotels may reopen to } \\
\text { accommodate local guests for leisure with safety measures }\end{array}$ \\
\hline 23 July 2020 & More than 49,000 cases of COVID-19 reported in Singapore \\
\hline 10 August 2020 & Local COVID-19 infection decreased and was reported at 188 cases \\
\hline 11 August 2020 & Local COVID-19 infection decreased and was reported at 61 cases \\
\hline 17 August 2020 & $\begin{array}{l}\text { Singapore and Malaysia established Reciprocal Green Lane and Periodic } \\
\text { Commuting Arrangement schemes for business travel }\end{array}$ \\
\hline 22 August 2020 & Local COVID-19 infection decreased and was reported at 50 cases \\
\hline 1 September 2020 & $\begin{array}{l}\text { Singapore and Brunei also established Reciprocal Green Lane for essential } \\
\text { travel }\end{array}$ \\
\hline 1 October 2020 & $\begin{array}{l}\text { Singapore Tourism Board begins accepting application from MICE } \\
\text { organisers with a capped of } 250 \text { persons }\end{array}$ \\
\hline 3 October 2020 & Local COVID-19 infection decreased and was reported at 6 cases \\
\hline 8 October 2020 & $\begin{array}{l}\text { Singapore will unilaterally lift border restrictions to visitors from Australia } \\
\text { - excluding Victoria state - and Vietnam }\end{array}$ \\
\hline 13 October 2020 & Singapore reported no local COVID-19 transmission \\
\hline
\end{tabular}

Source: (Chong, 2020; Goh, 2020; Ministry of Health, 2020c; Low, 2020; Tay, 2020g \& Yong, 2020) 